\title{
Laudation for PD Dr. Wolfgang Ahlf to celebrate his 65th birthday
}

\author{
Ulrich Förstner $^{1}$
}

Received: 8 July 2015 / Accepted: 12 July 2015 /Published online: 24 July 2015

(C) Springer-Verlag Berlin Heidelberg 2015

In 1982, the University of Technology Hamburg-Harburg (TUHH), Germany, installed a new section under the programme title "Preventive Environmental Protection Technologies in an Ecological Context". In retrospective, it was less difficult to find a director and a chief engineer, doctoral students and laboratory staff; rather, the search was for a broadly qualified biologist, who could manage the embedding of the other scientists and engineers within an ecological concept. The practical issues that the section needed to address were common knowledge in the "Hamburg industrial landscape": historical contaminated sediments in the Elbe, dredged materials in the harbour, arsenic in air and soil around the "Affi" (the Norddeutsche Affinerie, a copper ore refinery and well-known industrial polluter in the 1970s and 1980s that was close to Hamburg) and soon the situation culminating in the international case of dioxins at Georgswerder.

Professor Adolf Weber, director at the Botanical Institute of the University of Hamburg and an expert on environmental issues in the Hamburg State planning group, convinced a promising young colleague (Ahlf 1983) to join our team. At the end, even the administration at TUHH changed its strict department structure rules to provide a permanent position to Wolfgang Ahlf.

Wolfgang Ahlf and his "ecotoxicology" research group fulfilled its specific mandate in all respects. Our Monday morning meetings got instructions at different levels, from

Ulrich Förstner

u.foerstner@tu-harburg.de

1 Institute of Environmental Technology and Energy Economics, University of Technology Hamburg-Harburg,

21071 Hamburg, Germany scientific publishing to global environmental ethics, and our projects and those of the neighbouring departments were checked for their ecological correctness. The two big Collaborative Research Programs of the German Research Foundation (DFG), SFB 327 Interactions between Abiotic and Biotic Processes in the Tidal Elbe (1986-1995) and, particularly, SFB 188 Treatment of Contaminated Soil (1988-2000) profited much from Wolfgang Ahlf's competence, eloquence and ecological spirit. During all these years, one cannot remember the failure of any proposal when he was personally involved.

In our transdisciplinary view, one of the secrets for success of the Harburg ecotoxicologists was their pragmatic approach. From the beginning, the group focussed on interfaces and on real world situations rather than on models. The typical test systems for the study of competing sorption and uptake of contaminants by different substrates and organisms were two-chamber and multichamber devices (Ahlf 1985).

The biggest challenge for ecotoxicologists is the transfer of laboratory and field results into risk assessment schemes and finally into regulations. The activities of Wolfgang Ahlf during the last 25 years centred around microbial biotests for the toxicological assessment of contaminated sediments, both in the international network of the Society of Environmental Toxicology and Chemistry (SETAC) and with a national focus on the contact test (Feiler et al. 2013).

In 2002, Wolfgang Ahlf was appointed to the national committee of experts for the authorisation of plant protection products. Since 2003, the group undertook a new orientation in the direction of an ecological assessment of chemicals in foodstuffs.

Since the beginning of the Journal of Soils and Sediments in 2001 until 2015, Wolfgang Ahlf served as a valuable member of the Editorial Board and both his 
conceptual and practical input to Sediments Section 1 "Quality and Impact Assessment" (Ahlf and Förstner 2001; Ahlf et al. 2009) is highly appreciated.

Our best wishes are with Wolfgang Ahlf"s future expeditions into science. In 1994, his habilitation thesis on "Biotests on Sediments and Soils-Ecotoxicological Assessment of Contaminated Solid Matter" provided a remarkable source of references. Regarding the scientific excellence, the work could be seen even beyond the standard textbooks from the early 1990s. When we include his activities in the area of contaminated soils, with the pretension for utilizing biotests as a basis for remedial measures, there is only one consequence: "Write the book!".

\section{References}

Ahlf W (1983) The river Elbe: behaviour of Cd and Zn during estuarine mixing. Environ Technol Lett 4:405-410

Ahlf W (1985) Behaviour of sediment-bound heavy metals in a bioassay with algae: bioaccumulation and toxicity. Vom Wasser 65:183-188 (in German)

Ahlf W, Förstner U (2001) Managing contaminated sediments. J Soils Sediments 1:30-36

Ahlf W, Drost W, Heise S (2009) Incorporation of metal bioavailability into regulatory frameworks - metal exposure in water and sediment. J Soils Sediments 9:411-419

Feiler U, Höss S, Ahlf W, Gilberg D, Hammers-Wirtz M, Hollert H, Meller M, Neumann-Hensel H, Ottermanns R, Seiler T-B, Spira D, Heininger P (2013) Sediment contact tests as a tool for the assessment of sediment quality in German waters. Environ Toxicol Chem 32:144-155 